\title{
Malandros, María Lionza, and Masculinity in a Venezuelan Shantytown
}

Francisco Ferrándiz (Universidad de Deusto)

Para Omar y su estela de risas

2003

"Malandros, María Lionza and Masculinity in a Venezuelan Shantytown". In Changing Men and Masculinities in Latin America, ed. by M. Gutmann, Durham, Duke University Press, pp. 115-133.

\section{Mugshot}

Profile of E.H.: 27-years-old. ${ }^{1}$ Medium height. Slim. Dark skinned, mestizo. Bright black eyes. Visible elbow scar. Swinging body language. Calé-popular speech. Worn out T-shirt. Sport shorts. Baseball cap. Barrio-shantytown dweller. Street rambler. Formally unemployed. No bank account. No registered property. Uneducated. Undernourished. Short-term jailbird. Spiritist.

\section{Click.}

If we were to regard E.H.'s public persona from the point of view of Venezuela's prevalent official discourses and practices of exclusion, he would no doubt belong to the brand of dangerous barrio (shantytown) youngsters and grown-up men lumped under the label of malandros (thugs). As an ordinary inhabitant of the shantytowns of Caracas, E.H. personifies in his very flesh and personal style the suspicious appearance named by Julio de Freitas (1995: 3-4) as typical of the streets of Venezuela's capital city. E.H. is an ordinary tierrúo ${ }^{2}$ who, once out of his immediate urban territory, his shantytown, frequently notices that others cross the street to avoid him, that merchants lock their shops upon spotting him, that police officers comment on how he does not fit in and that they may reach for their guns or harass him, that taxi drivers speed away while refusing him a ride. ${ }^{3}$

Given such a hegemonic, essentialized, and internalized view of men living in the shantytowns, in all likelihood E.H. is just a hopeless and genuine delinquent. Yet there is more. Men from the popular urban sectors in Venezuela often are depicted as savages, barbarians, and parasites, people who are predisposed to random violence owing to little more than their "lack of character." ${ }^{4}$ In a context in which social stigma is assigned randomly upon a whole population according to crude considerations of class and gender, being a malandro thus becomes the preeminent form of masculinity available to male inhabitants of the shantytowns. The social, psychological, and cultural mugshot of a stereotypical thug of the shantytowns communicates a disturbing image of a tough guy, drug addict, heavy drinker, lawbreaker, sexual predator, irresponsible father, merengue and popular salsa fan, a man bent on easy and fast money, a treacherous gambler, mostly uneducated and coarse, one deeply immersed in the culture of weapons, unreliable, criminal, vengeful, fearless of an early death, a ruthless 
assassin, someone who would kill for just a pair of shoes, and, ultimately, a man who is thoroughly incorrigible.

The widespread influence in the social imaginary of this hegemonic prototype of the malandro and popular lawbreaking man no doubt acts to obscure the structural causes of poverty, unemployment, and "informal" employment in the Venezuelan popular urban territories. Simultaneously, this same process which in Venezuela produces delinquent and disposable bodies_particularly male bodies_also turns most youngsters and men in the shantytowns, regardless of their particular biographies or life projects, into potential targets of systematic discrimination, arrest, torture, and violent death by the state and its agents. ${ }^{5}$ E.H., like most of his peers and other barrio men, lives his life trapped in a forced gender identity which mostly breeds stigma, suspicion, and abuse.

Of course life in the shantytowns of Caracas, Venezuela, is complex. Conditions are ripe for the emergence of pockets of violence. Residents have to endure the neighborhood professional criminals, the murderous practices of petty and grand delinquents, as well as many other forms of structural violence, not the least of which is wholesale police repression. Many men in Caracas are raised and expected to conform to tough models of masculinity. Yet the presence of criminality in the shantytowns and the dominant cliché of masculinity as a realm of impenitent delinquency does not, as certain public discourses would have it, transform all men into undesirable and menacing offenders, beyond redemption, worthy only of extermination.

In many ways shantytown dwellers have absorbed these hegemonic stereotypes about men and masculinity which circulate in the media, political policy reports, and other official sources of public opinion. "This barrio is still clean, believe me," Hermes told me one day in the heart of one of the more infamous popular neighborhoods in Caracas, Los Mangos de La Vega, a place other friends advised me not to go near even in daylight. "You can come here anytime, if you're careful, of course. But never ever go to any of the shantytowns of El Valle. All you'll find there are puros malandros. Dangerous men. There they'll kill you for nothing." Most barrio residents are quick to point out that the stereotype about their own neighborhood does not accord with their own experiences, whereas they are quite sure that malandrismo is the dominant male way of life in other areas of the city with which they have less familiarity. Therefore they are as eager to express their negative opinions about other poor neighborhoods as the inhabitants of middle and upper class areas are quick to denigrate all popular barrios.

This paper is concerned with the interface of youth, gender, stigma, and everyday violence in urban Venezuela, resulting in the production of what I call a wounded masculinity. Drawing upon the life history of E.H., we trace the parameters of structural and discursive violence to establish the stigmatized and coercive framework in which E.H. has deciphered his life and constructed his gender identity. Given the generalized nature of outcast, delinquent, and highly restricted masculinity in Caracas's shantytowns, E.H.'s life may seem unexceptional. In fact, at first glance E.H. seems to have done no more than travel through life on his way to becoming a reckless criminal. 
Yet his biography is multifaceted, full of texture, and understanding how he has employed diverse survival strategies calls for a nuanced understanding of what it means to be a man in Venezuela's urban peripheries. Moving from street child to shoe shine boy, abandoned car dweller, drug addict, gambler, petty thief, informal worker, occasional prisoner, enthusiastic looter during the caracazo, ${ }^{6}$ husband and father, anthropologist's informant and spiritist healer, during his life E.H. has journeyed across the perimeters and territories of social and gender stigma. His categorically ambiguous experience of being a man in the informal sector of this once rich oil country is not uncommon. ${ }^{7}$ Many men in the shantytowns are trapped in highly gendered identity and behavioral expectations which, as in E.H.'s case, collide with their life projects.

\section{A Picture in Motion}

It was no easy task to get E.H. to talk about his life. The life he had lived was, in his opinion, too average, worthless of any attention. Yet this history, perhaps due to its "antibiographical" status, ${ }^{8}$ may be important in contributing to the understanding of how Venezuela's modernity and its associated ideologies are experienced at an everyday level in Venezuelan shantytowns. Although his style of life does not exhaust all possible forms of male experience in the shantytowns, it is representative of the lives of many men who unravel their lives in contexts of low intensity urban violence. Thus the central question guiding this study of one man's ordinary life in a Caracas shantytown: How has E.H. experienced, endured, and eventually resisted forms of masculinity imposed on him by the very act of beginning life in a poor family in the urban popular territories?

E.H. was born in a shantytown on the southern edge of Caracas to a woman E.H. himself calls "a cabaret lady" and a man with whom E.H. has had little contact in his life. Unhappy and harassed at home, he also resisted going to school, though to hide his truancy he remembers giving his mother fake drawings and other kinds of invented homework. Mostly, E.H. spent his time roaming the streets of his shantytown for money, play, and excitement.

I'd take off with my notebooks and stuff but I would never make it to school. And when I got home I had my pockets full and would bring every thing I could think of to my mom. Food and everything, you know. And I still had some money left. But when my mother got home, always drunk, she would start tormenting me. She would send me to the shower and then hit me with her belt, after my back was wet. I guess her bad temper ended up driving all of us mad.

As his mother, Rosa, suggested to me, her brutal behavior toward her childrenfive boys from different fathers-stemmed mainly from her desire to toughen them so they would be ready for the kind of life she said she expected for them. ${ }^{9}$ When E.H. was eight-years-old, weary of his mother's beatings, he ran away from home and started a life in the streets, which he found to be a distinctively male space of socialization. ${ }^{10}$ In dire straits and unsupported by his family, E.H. was quickly forced to master the circuits of the informal economy, the rebusque, in his barrio. He survived shining shoes and cleaning windshields, tasks he had occasionally performed before he 
left home. He still remembers the sense of empowerment he achieved by earning his own money and fully enjoying his freedom in the streets-no timetables, no formal education, no family obligations.

During this time E.H. slept, along with other kids, in abandoned cars on the outskirts of his barrio. With the promise of daily food and clean clothes, his mother would come by once in a while to try to convince him, "in quite a loving way," to return home. And on more than one occasion he did go home for a while. But before long he would confront the old patterns that had driven him away before and, inevitably, he returned to the streets. There, E.H. was regularly exposed to the most extreme and routinized forms of street violence. When he was barely ten, one of his older brothers was killed in a gang fight. Only six months later, a second brother died in similar circumstances.

E.H. told me of another incident that took place a little later, one which remained a crucial reference point in his memories of childhood. Now the oldest son alive, this incident pushed his emergent masculinity to the fore and led him for the first time into a potentially serious skirmish with the police and judicial system. After finding his mother severely beaten and bleeding in the street one day, E.H. felt compelled and felt pressure from others to kill his mother's assailant in order to restore the honor of the family. This was true despite the fact that E.H. was a runaway and at the time had a tormented and distant relationship with his mother. When he was already in the chase, a female relative talked him out of seeking revenge by convincing $\mathrm{E} . \mathrm{H}$. that if he were caught he would destroy his own life for that of a worthless man. When E.H. told me about this incident a few years later, it seemed that he had never been truly comfortable with the status he had been obliged to assume as the main protector of his family's reputation. In what many people, including his mother, considered a lack of manliness, E.H. allowed pass the opportunity to retaliate and he returned to the streets to live his own life. "[But] it was not cowardice on my part not to kill that sucker," he told me. "Simply that I had a really pure heart. I still see the guy who did it around, and sooner or later I'll get him with a few needles."

Yet at this point, E.H. was still a child in many respects. First, he had run away from home; then he had failed as his family's defender when he showed himself incapable or uninterested in hunting down the man who had assaulted his mother. In his quite conventional fall from grace, E.H. became ensnarled in street life. He became a drug addict, a petty trafficker of marijuana, amphetamines, and aguardiente-liquor. He became increasingly involved with gangs of street children and even of older men.

I started to consume drugs, to brag, and to play games of chance with malandros, but true malandros, let me tell you. I was the only pelao-kid hanging out with them. Even though I was a kid I could easily drink three bottles of caña clara-rum liquor and still be able to stand up. I tried to be nice to everybody and nobody harassed me. Whenever we took pills with liquor we'd go crazy. We became fearless. We felt we could fight three guys, or five guys, if we wanted, I mean fist fights, you know. Once they got me and hit me really hard; I was left 
unconscious down there at the edge of the barrio and nobody cared. I don't remember how long I lay there. Next day my whole body hurt, but I took a few pills and the pain disappeared. I was fine. You feel like superman.

\section{Fuel Embodied}

E. $H$. remembers this time of initiation in male routines and excesses in a confused way. He seems always to have been intoxicated, moving from abandoned car to abandoned car, learning to be a real man among real malandros. Yet in their toughness and apparent invincibility, he and his peers were strikingly vulnerable even when high on drugs. At his mother's house, he told me a story which revealed the traumatized space in which many barrio neighbors led their everyday lives. The low price of gasoline, subsidized by the Venezuelan state, turned this product into a preferred narcotic for the generation who shared the streets with E.H. in the late 1970s and the 1980s. At times, the hallucinations induced by gasoline, the perverse fuel of Venezuela's modernity, were crude visualizations of the structural exclusion to which these youth were subject and illustrations of the local, wounded space of their everyday experiences. ${ }^{12}$ E.H. conveyed such images of terror to me one afternoon in his shanty, with a vision which was still vivid in his memory.

When I was in the streets, I used to consume gasoline a lot. We would get a bottle of gasoline and inhale in it. See, this stuff makes you see planes, like planes falling down on you, and you get terrified and run like crazy. Or, then, like a train at full speed trying to run you over. Can you imagine? A train running all over the place in this cerro-hillside? It doesn't make any sense. And suddenly you can see a whole army chasing you down, and then you start running all over the hill like crazy, looking for a safe spot. Where? People thought we were nuts; they just couldn't understand. But it was so real to us. And after you came out of your burrow, so to speak, you were still asking your panas-buddies in terror, "Are the police still here? Are the authorities still after us?" "What authorities?" they'd say. "There's nothing here."

They had every reason to fear. Since they began to toddle, these youths had been officially marked as incurable delinquents, as children without childhood, and later as youth without a future. Young or mature, respectable workers, students, or evildoers, shantytown men are indiscriminately treated as malandros by the various police agencies and the military. "There is some kind of death penalty for barrio men," E.H. and his spiritist friend Maimai told me on one occasion. "The order from the government is 'Shoot the malandros, plomo al hampa, lead for the scum."'13 That could mean for them or any of their peers and neighbors.

As is frequently the case in poor areas of Caracas, at times during my fieldwork I could not enter E.H.'s shantytown because it was occupied by police carrying out "cleansing operations." During these interventions, as my informants (most of them spiritists) declared, no one was safe from indiscriminate harassment, and shootouts 
were all too common. ${ }^{14}$ Whether in the narrow streets and alleys or hidden in fragile shanties, no one could scape the crossfire.

To be sure, police harassment and military hair triggers are not the only forms of daily danger in the shantytowns. Life in the heart or on the periphery of delinquency always involves long-lasting culebras. Culebra literally means "snake," and in Caracas it refers to a enduring feud. It can apply to a dispute between people, neighborhoods, or situations - or a combination of them-that may eventually erupt into violence. Being able to negotiate these culebras successfully, to impose fear or respect into your culebras, is highly valued as a sign of manliness in the streets. After seven years wandering around, E.H. was profoundly immersed in this world of toughness, aggression, and payback. Within this logic of masculinity, he proudly carried a "medal" in his right elbow, a scar from a gunshot wound he received in an attack that stemmed from the deaths of his brothers. Yet at that point in his life, he felt trapped.

When I reached fifteen, I started to wonder about my life and my expectations, and I decided that I wanted something else. I could see some younger kids and I thought, "These guys will be something in life, and I will still be in this mess." The life I was living, you know, was a "bad life." It was not appropriate for me. I wanted out.

A few years later, on July 5, 1985-a date he emphasized a few times during our conversations-he made the decision to leave the streets. As life choices for barrio men are limited, particularly when these men are branded with the stigma of the malandro, the only way available for a total break with his former life was for E.H. to join the army. He was eighteen. The army offered him a respite from the pressures of the streets and a fresh environment from which to reconsider his life. According to his narrative, he used military discipline against his addictions and managed to quit alcohol and drugs, at least partially. He did not stop consuming drugs and alcohol entirely, but these substances stopped being central to his identity and his relationships with other men. He thinks of his stay in the military as a turning point in his life, and he showed me his military ID with pride in order to demonstrate, I think, one of the few pieces of evidence besides his police record that he has of his legal existence.

E.H. returned to Caracas resolved to start anew, but found himself haunted by unresolved issues that he just could not ignore. He soon realized that there were old paths that he had go round, risky gatherings to avoid, certain police officers to evade. His old culebras, even if subdued, were still alive. And new and disturbing ones appeared. His younger brother was killed by a gang when he was still a teenager. Later his brother's killers, led by the well known gangster Canelón, showed no compunction in roughing up those who attended the funeral. In what he considered one of his most visible acts of public courage, E.H. confronted them, but was outnumbered. Still, he was one of the few who managed to hold on to his wallet. With the death of his third brother, E.H. was quickly transformed, one more time despite his best intentions, into a main participant in a new blood feud. Again expectations were raised in the shantytown as to how he should react to this new murder. 
E.H. was furious with the head of the gang that had enlisted his brother to fight Canelón's gang. According to E.H., this malandro was recruiting and arming youths like his deceased brother to fight on the front lines against other gangs for control of the barrio's territories. He thought this was immoral and cowardly even according to the codes of street violence. Yet E.H. decided to start with Canelón. He went to the top of the hill with a gun to avenge his brother. Once he arrived he was promptly surrounded by members of the gang who told him that the blame was not theirs. Rather, E.H. should confront the leader of his brother's own gang, the one who put him at risk. Then, looking downhill, one of the rival gang members gave E.H. the gun that had been used to kill his brother, and urged him to retaliate against the appropriate person. E.H. knew that his life had been spared so he could carry out this dirty job for Canelón and his gang. He never used the gun, though, and instead gave it to a friend. Again, he refused to take part in violence. Presumably, in the eyes of his culebras, he gave up a good share of masculinity along with that symbolically and emotionally charged gun.

Adding to his renewed tribulations in the streets, employment opportunities in the formal sector were slim. E.H. applied a series of more or less legal strategies for survival in the informal sector. In times of dire need, he resorted to pickpocketing. A petty theft in the popular market where E.H. often spent time in search of low paid and temporary jobs resulted in his main brush with the judicial and penal system. After he was arrested, he spent two terrifying weeks in jail; that he was released so quickly was only because of the insignificance of his offense. According to E.H., a compassionate lawyer or secretary tore up the record of his crime, "ras, ras, ras, ras," and let him go.

I don't recommend prison to anybody. In jail, I had to sleep very close to the bathroom door, and everybody had to step on me to get in, to jump "over my dead body," you could say. As people were released, I managed to move my sleeping place away from the bathroom, little by little. I remember I had my life threatened by one guy who was trying to control the cell. He bragged that he was there for theft, rape, homicide, and demanded that everybody had to obey his orders. He accused me of having turned him in. "You are wrong, you are wrong," I would tell him. He was testing me, ready to stab me to death if I flunked. These guys are really satanic, let me tell you. They do not stab you once in the heart, you know. They sew your whole body up. They leave you like a colander and nobody cares. Fortunately I managed to get out of that hell after a couple of weeks. I had to beg and scream out my innocence to the official who was there, but I was released with no charges.

Due to the cruelty of Venezuela's penal system, and to the sluggishness and corruption of its justice system, E.H. was truly blessed to come out relatively unscathed. Indeed, aside from the constant tragedy that was his family, E.H. was somewhat lucky; he could even contemplate being able to emerge from his years in the streets alive and without any serious blood debts. His police record was short and his experience with institutionalization minimal, albeit traumatic. Nonetheless, until the day he dies, E.H. will be a malandro. This has been his fate from the day he was born. With few chances of 
securing steady employment or being considered an integral part of Venezuela's future, no matter how much he struggles, E.H. will never shake off his murky past in the streets, his suspicious appearance-attached as they are to his skin and his cultural style-and his culebras. He had always been uneasy with the expectations of others and, after his short jail term and his experience with Canelón and his gangland associates, E.H. definitely wanted out, somehow....

Although he never told me exactly how he turned his life around, the fact was that by the time I met him E.H. had reconciled with his mother-"There is only one mother"- and eventually married a young woman from his shantytown, with whom he had two children. In the meantime, he had also become a spiritist. These changes in his life entailed a reconsideration of the terms and activities by which he constructed his masculinity.

\section{Shaking Uncontrollably}

I met E.H. in January 1994, deep in the forest on the mountain of Sorte, the main pilgrimage site of the Venezuelan spirit possession cult of María Lionza, during an early fieldwork stay with a spiritist group based in E.H.'s shantytown. ${ }^{15} \mathrm{He}$ had joined the group a year earlier, when he discovered in spiritism a fresh environment in which to make a living and refashion his identity. During our sojourn in 1994, we spent four days on the mountain, while the spiritist party performed healing rituals and initiation rites. A ceremony performed to develop E.H.'s mediumship ended in failure when he did not "receive" any full spirit, only mild trembling.

During the nightlong ceremonies, E.H. asked the spirits to disclose the whereabouts of Canelón. After a member of his gang killed E.H.'s little brother, he had twice tried to murder E.H. Now Canelón had disappeared from the shantytown and E.H. wanted to know if he was about to return or if he might even be dead. Eventually a popular malandro spirit, Ismael, arrived in the body of a medium. ${ }^{16}$ The spirit told E.H. that Canelón was out of the picture for good, and therefore that E.H. did not have to leave the shantytown. E.H. could disengage from at least this culebra and would be left alone.

After our initial contact in Sorte, I began to regularly visit some of the members of this small spiritist group in Caracas. In addition to its religious routines, the group also functioned as an economic unit, at least for its three core members. In the wee hours of the morning, Maimai, Roberto, and E.H. would often go to a nearby wholesale market to buy a few products like fruits and vegetables. Maimai had bought an old and shabby van with the money he won in a lottery, on a number recommended by one of their main spirit protectors, the Viking Robinson. Most of the petty economic activities of the group revolved around this vehicle. After securing various inexpensive products, they would drive to the foot of the shantytown, place them in the open door of the van and await potential buyers. With the fruits and vegetables, they also offered spiritist services like counseling, diagnosis, spiritual checkups, and "tabaco smoking."17 
During the day, Maimai stayed with the van, their base of operations, while the rest of the group looked for alternative ways to earn some money. E.H. usually went back to the market to work as carretillero-loader and gofer. But competition was high, local mafias were very active, and sometimes E.H. would come back with empty pockets. Occasionally he worked as a bricklayer, but that was as a last resort.

By the end of the day, when sales had declined, Maimai split the sparse revenue among all those (other than me) who had joined in the group's activities that day. The money was divided into uneven shares depending on the nature of each member's work contribution and the total time each had spent under the sun. On particularly bad days a system of reciprocal loans went into effect, as E.H. or Roberto shared the money they had earned in their separate activities. When everyone was satisfied that the money had been "evened out" for the day, they bought food for their families. The mandatory harina de pan (maize flour) to cook arepas, and if they were lucky something extra like chicken, canned sardines, or raw liver, depending on the earnings of the day.

In this new role of family provider, during this time E.H. was also building atop his mother's concrete shanty a wooden shack_rancho de tablas-for his family. He roamed the dumps surrounding the wholesale market, also a very competitive environment, looking for scraps in the garbage. The most valued were wooden planks and zinc sheets. Sometimes he walked by content with some new found treasure on his head, ready to climb to the top of the hill. Other times he returned frustrated with only dirty fingers. Not well secured to his mother's shanty, E.H.'s shack was always on the verge of collapse from heavy rain and wind. Yet sprucing up that precarious home, the only shelter E.H. was able to provide for his nuclear family, became a major life project for him.

Regardless how well they had done in selling and building, their day was far from over when they closed their stall. In the late afternoon, the group usually drove to a neighboring outdoor spiritist shrine to look for potential clients, and to develop their own mediumship. It was during these afternoon ceremonies, and during the occasional ceremony in their shanties, that I could follow E.H.'s materia-medium activities. As an apprentice at the time, E.H. was looking for affinities in the pantheon of spirits in order to start formal negotiations with certain spirits who might possess his body. From the great array of spirits in the cult, mediums select those with whom, for one reason or another, they may feel a special connection. The patient development of these affinities is crucial to the future spiritist persona of the medium, as well as to his/her public identity as a healer. Quite often, in fact, the name of a particular spirit becomes associated with that of the medium.

E.H.'s attempts to be a responsible father and maintain a monogamous marriage already represented a rupture from what was expected of the stereotypical malandro. His development as a medium provided him with additional ways of interacting according to different models of masculinity. Like some of his spiritist companions, I was surprised initially by E.H.'s steadfast refusal to be possessed by malandro spirits, who embody most traits of the stereotypical delinquent and constantly refer to scenarios 
of street violence. They thus represent the kind of masculinity he was trying to escape from at that point in his life. He showed instead an interest in simultaneously approaching three non-malandro male spirits: the Indian cacique Tacataca, the African Changó, and Raúl Sánchez Valero, an old healer from the Andes. The spirits in the pantheon always hold many popular memories which are mapped in sophisticated ways onto the bodies of the mediums during trance. These corporeal memories are unquestionably gendered memories. Speaking in overall terms, the Indian male warriors such as Tacataca exhibit-and transfer to their mediums-local senses of courage, dignity, loyalty and resistance. As victims of the colonial regime, they stand for a wounded, sober, yet heroic masculinity. The Africans, including many members of the Cuban santería like Changó, loosely convey experiences of suffering from the time of slavery in Venezuela. They are the tortured, stigmatized, forgotten, and maroon fighters against colonial power. And chamarreros such as Sánchez Valero stereotypically elicit nostalgic memories of rural Venezuela. As male spirits, they usually come across in possession as womanish, obscene, overly sexist, heavy drinking, humorous, grouchy, wise, tender, reliable.

Identification by mediums with the spirits possessing them goes beyond nominal attributions. During trance materias feel them deep within their bodies. Their smell, their taste, their weight, their caprices. Even outside ritual settings, in their everyday life, they perceive their spirits inside their skins. They constantly talk to them and smoke cigars to get answers. They sense the spirit's evanescent presence in breezes, temperatures, noises. Spirits also infiltrate their gestures, tastes, and moods. In fact, many male mediums refuse to be possessed by female spirits because they feel that these spirits would feminize-and thus publicly ridicule-them. ${ }^{18}$ Mediums acquire, in this way, a new corporeality in their constant rubbing against the spirits, and this kind of identification, which crosses all sensorial paths, entails a whole universe of deeply gendered intimacy unknown to the non-initiated. The three categories of spirits selected by E.H. offered him three different corporeal "masculinity tracks" to refashion his gender identity away from its hegemonic inscription as malandro.

When I met him, E.H. was fully engaged in his spiritist growth. Still a beginner, he was just learning the ropes of trance, slowly discerning the different facets of this new form of closeness. E.H. had built an altar in his shack which he tended daily. He prayed to his select spirits, lit candles for them, smoked tobacco, carried images of them in his pockets, thought about them often. In the afternoons or weekends, he would gather with his spiritist companions and organize a ceremony. They created imaginative sacred spaces_velaciones_from spiritist symbols in order to lie down and invoke the spiritual forces. They carefully tended each other's rituals. They gave their entire bodies over to spiritual possession. And each attempt by E.H. to enter a trance resulted in uncontrollable shaking until he was absolutely drained of energy.

Presumably if E.H. continued his spiritist development properly he eventually would become a good medium able to enter sophisticated and more serene trances. But E.H.'s uncontrollable shaking is the essential image I recall from our relationship. E.H. shaking in his shanty in front of his spiritist altar. E.H. shaking in outdoor shrines, 
his arms extended ahead in parallel to one another, his eyes rolled backwards. Convulsions are not uncommon in such early phases of spiritual development, when the medium is learning to embody certain previously unknown presences and spirits fight among themselves for preeminence. Yet in E.H.'s case they were clearly connected to an uneasiness he had felt all his life about who he was and what was expected of him. E.H.'s shaking was a signal of transition. He was shaking against a stereotype imposed and acted upon him, against a wounded masculinity, against powerlessness, against the killings and the mourning, against the lack of a future. He was shaking for a new persona, for a renewed sense of gender and identity, for a fresh horizon in his life.

\section{NOTES}

${ }^{1}$ This was in 1993-94, when I met E.H. during fieldwork in Venezuela.

${ }^{2}$ A derogatory term for barrio dweller, meaning literally "mud dweller."

${ }^{3}$ Fieldwork (1993-94) on the cult of María Lionza was supported by a MEC/Fulbright doctoral grant, and by R.L. Lowie and R.H. Olson travel grants (UC Berkeley). My thanks as well for a Rockefeller Fellowship, administered through the Institute of Violence and Survival at the Virginia Foundation for the Humanities and Public Policy (VFH) during Fall of 1996. An earlier version of E.H.’s life story was published in Ferrándiz 1999a.

${ }^{4}$ See Coronil and Skurski 1991:322-334; España 1993:160-161. In fact, these designations are generally extended to all barrio dwellers.

${ }^{5}$ Police operations on shantytown men—delinquents—are one crucial way in which these stigmatizing stereotypes are acted upon in deeply traumatic ways. For an expanded discussion of these operatives, including kidnapping, torture, and indiscriminate arrests or deadly shootings, see PROVEA (1992), or any of their annual reports. For a study of the criminogenic quality of these state interventions (i.e., the production of penal antecedents for many men), see Tosca 
Hernández (1989; 2000). For testimonies and analysis of repressive practices on street children, specially boys, see Pedrazzini and Sánchez 1992; Duque 1995; and Márquez 1999.

${ }^{6}$ El caracazo refers to a widespread (and violently repressed) popular rebellion against austerity measures that took place in Venezuela in 1989. For an analysis of the social wounds left behind by el caracazo, see Coronil (1997) and Tulio Hernández (2000).

${ }^{7}$ In this sense, the task of deconstructing the gendered dimensions of the malandro parallels Gutmann’s (1996) revealing critique of Mexican stereotypes of machismo.

${ }^{8}$ Ignasi Terradas shows us how fruitful it can be to preserve from oblivion those anti-biographies or lives "which reveal the silence, the emptiness, the chaos that a certain civilization has cast over a certain person, making him/her conventionally insignificant” (1992:13).

${ }^{9}$ Rosa herself had been severely beaten by her mother and quite a few men during her life. ${ }^{10}$ Although there are obviously girls and young women on the street everywhere in the world, often engaged in prostitution, as many commentators have written, most of those living in the streets are boys. Further, while these factors vary crossculturally, girls tend to be more constrained than boys by domestic tasks and compromises, not the least of which is raising their siblings. For Latin American perspectives, see Scheper-Hughes and Hoffman 1994:18-19; and Márquez 1999.

${ }^{11}$ Here E.H., who was a spiritist when I met him, is referring to the possibility of settling this old account through magic.

${ }^{12}$ It has become commonplace among critics of Venezuelan oil modernity to resort to metaphors such as “malediction,” “bulimia,” “wreckage,” “perversion,” and “devil’s excrement” to characterize the impact of the oil economy on the economic, social, cultural, political fabric of the country. See, for example, Izard 1986; Briceño León 1990; Watts 1992; and Coronil 1997. 
${ }^{13}$ What is known in Venezuela as the doctrina Betancourt, "shoot first, then ask." See PROVEA 1992:28. It is common to hear testimonies in the shantytowns and read reports in the press about men and children who are considered sane by their neighbors before they are killed by police, who are then, post mortem, officially declared to have been dangerous delinquents. ${ }^{14}$ PROVEA (1992: 17) has denounced human rights abuses and violations committed during these police operations, and stated that, contrary to government assertions, they should not be blamed on the "excesses of isolated officers acting on their own." In their own words, "what we have is a systematic pattern of repression which is painstakingly elaborated, learned, and conducted by the police corps, aimed at creating a disorienting social environment among the population which prevents the articulation of any organizational movement of resistance against the implementation of a certain [liberal] economic program with well known results.”

${ }^{15}$ For classic and more recent analysis of this widespread form of spirit possession in Venezuela, see Pollak-Eltz 1972; Martin 1983; García Gavidia 1987; Barreto 1990, 1994; Clarac de Briceño 1992; Taussig 1997; and Ferrándiz 1992, 1995, 1996, 1997-98, $1999 b$.

${ }^{16}$ For an analysis of the impact of malandro spirits in the cult of María Lionza in the early 1990s, see Ferrándiz 1996 and 1999c.

${ }^{17}$ Divination with cigars.

${ }^{18}$ Although this does not apply in a reverse fashion.

\section{BIBLIOGRAPHY}

Barreto, Daisy. 1987. María Lionza: Mito e historia. Caracas: Escuela de Antropología/Universidad Central de Venezuela. Unpublished manuscript. 
. 1990. "Perspectiva histórica del mito a María Lionza.” Boletín Americanista 39-

40:9-26.

. 1994. "Plasticité et résistance: Le mythe et le culte de María Lionza au Venezuela.”

Gradhiva: Revue d'Histoire et d'Archives de l'Antropologia 15:81-88.

Briceño León, Roberto. 1990. Los efectos perversos del petróleo. Caracas: Fondo Editorial Acta Científica Venezolana.

Clarac de Briceño, Jacqueline. 1992. La enfermedad como lenguaje en Venezuela. Mérida: Talleres Gráficos Universitarios.

Coronil, Fernando. 1997. The Magical State: Nature, Money and Modernity in Venezuela. Chicago: University of Chicago Press.

Coronil, Fernando, and Julia. Skurski. 1991. “Dismembering and Remembering the Nation: The Semantics of Political Violence in Venezuela.” Comparative Studies in Society and History, 33: 288-337.

De Freitas, Julio. 1995. “Bárbaros, armados y peligrosos: La eficacia del discurso sobre la violencia popular urbana.” In Historias de identidad urbana: composición y recomposición de identidades en los territorios populares urbanos. Emanuele Amodio and Teresa Ontiveros eds., pp.147-160. Caracas: Fondo Editorial Tropykos.

Duque, José Roberto, and Boris Muñoz. 1995. La ley de la calle: Testimonios de jovenes protagonistas de la violencia en Caracas. Caracas: FUNDARTE.

España, Luis Pedro. 1993. “La naturaleza de la violencia social.” SIC 554:160-162.

Ferrándiz, Francisco. 1992. “Dimensions of Nationalism in a Venezuelan Possession Cult.” Kroeber Anthropological Society Papers 75-76:28-47. 
. 1995. "Itinerarios de un médium: espiritismo y vida cotidiana en la Venezuela Contemporánea.” Antropología 10: 133-166.

. 1996. "Malandros, africanos y vikingos: violencia cotidiana y espiritismo en la urbe venezolana.” In Antropología de América Latina. Carlos Caravantes ed. Zaragoza: Actas del VII Congreso Nacional de Antropología Social, pp. 125-137. . 1997. “A Trace of Fingerprints: Displacements and Textures in the Use of Ethnographic Video in Venezuelan Spiritism.” Visual Anthropology Review 13(2):19-38. . 1999a. "Brevísima historia de E.H.: Espacios de trauma, estigma y peligro en las

vidas de los niños y jovenes de los barrios venezolanos.” Antropología de las edades. Carles Feixa, ed. Pp. 181-190. Santiago de Compostela: FAAEE/AGA. . 1999b. “El culto de María Lionza en Venezuela: Tiempos, espacios, cuerpos.” Alteridades 9 (18):39-55. . 1999c. “Juventud, estigma y violencia: el caso de los ‘espíritus malandros’ en Venezuela.” Joven(es) 8: 186-212.

García Gavídia, Nelly. 1987. Posesión y ambivalencia en el culto a María Lionza: Notas para una tipología de los cultos de posesión existentes en América del sur. Maracaibo: Universidad del Zulia.

Gutmann, Matthew C. 1996. The Meanings of Macho: Being a Man in Mexico City. Berkeley: University of California Press.

Hernández, Tosca. 1989. “Los problemas de la legitimación: la legitimación de los problemas sociales”. In Legitimidad y sociedad, L. Gabaldón et al. eds., pp. 113-178. Universidad de los Andes: Alfadil/Trópicos. . 2000. “El desafío de la violencia en el actual sistema político venezolano.” 
Unpublished Manuscript.

Hernández, Tulio. 2000. Celebración de estar vivos. Caracas: Biblioteca de Autores y Temas Tachirenses.

Izard, Miguel. 1986. Tierra Firme: Historia de Venezuela y Colombia. Madrid: Alianza America.

Márquez, Patricia. 1999. The Street is My Home: Youth and Violence in Caracas. Stanford: Stanford University Press.

Martín, Gustavo. 1983. Magia y religión en la Venezuela contempránea. Caracas: Ediciones de la Biblioteca de la Universidad Central de Venezuela.

Pedrazzini, Ives, and Magaly Sánchez. 1992. Malandros, bandas, y niños de la calle: Cultura de urgencia en la metrópoli latinoamericana. Caracas: Vadell Hermanos Editores.

Pollak-Eltz, Angelina. 1972. María Lionza: Mito y culto venezolano. Caracas: Universidad Católica Andrés Bello.

PROVEA. 1992. Situación de los Derechos Humanos en Venezuela: Informe Anual (Octubre 1991-Septiembre 1992). Caracas: Programa Venezolano de Educación-Acción en Derechos Humanos.

Scheper-Hughes, Nancy, and Daniel Hoffman. 1994. "Kids Out of Place.” NACLA: Report on the Americas XXVII (6):16-23.

Taussig, Michael. 1997. The Magic of the State. New York: Routledge.

Terradas, Ignasi. 1992. Eliza Kendal: Reflexiones sobre una antibiografía. Bellaterra: Servei de Publicacions de la Universitat Autónoma de Barcelona. 
Watts, Michael. 1992. “Oil as Money: the Devil’s Excrement and the Spectacle of Black Gold.” In Money, Power and Space. S. Corbridge, R. Martin, and N. Thrift eds., pp. 406-445. Cambridge: Blackwell. 